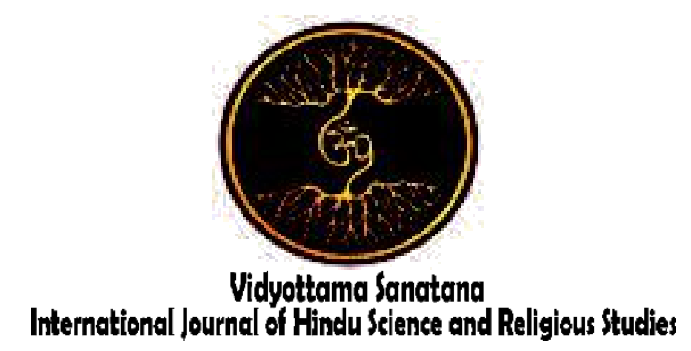

Vol. 3 No. 1 May 2019

\title{
THE EMPOWERMENT STRATEGY THROUGH SPIRITUAL EDUCATION (EDUCARE) TOWARD GEPENG IN DENPASAR
}

\author{
By: \\ Ni Ketut Srie Kusuma Wardhani \\ Institut Hindu Dharma Negeri Denpasar \\ E-mail : kusumasrie@ihdn.ac.id
}

Received: March 11, 2019

Accepted: May 22, 2019

Published: May 31, 2019

\begin{abstract}
Gepeng is not only a social pathology or deviant behavior but a case of subculture in the hegemonic, marginalized, and exploitative position. Gepeng is poverty production and poverty is a product of unequal political economic mechanism of the society. This condition has improved the production of empowerment programs. The research showed that Educare is the most strategic empowerment. The scope of problems in this research was about the empowerment strategy of Educare on the alleviation of Gepeng at Denpasar City. The empowerment through the emphasis of spiritual education (Educare) is very potential to transform the personality or and the Gepeng culture. The community adoption program with the Educare philosophy done by the education human value method and applied the three parts, they are education, service (seva), and spiritual. The process of transformation, intellectual emancipation and self-realization is the goal of this empowerment program. The essence of Educare empowerment program is to get the transformation with the social emancipation through self-reflection, positive restructuration (transformation), and to make more access productive capital after Educare program.
\end{abstract}

Keywords: Empowerment, Practice, Gepeng, Emancipation, Hegemony, Poverty, Educare

\section{Introduction}

Gepeng is someone who is homeless and lives inadequately, often encounters discrimination, social alienation, and is considered a marginal group. It is a profession that requires symbolic modalities of poverty. It can be seen from how they dress apprehensively, behave that causes a certain sense of pity, construct poverty identity as a symbolic modality of Gepeng, 
to the exploitation of children which results in structural poverty in themselves.

According to the Bali Provincial Government (2005: 5), poverty is a situation of inadequacy which occurs not because it is desired by the poor, but because it cannot be avoided by the power that is on it. People know that Gepeng as a group of people who are marginalized. Most of them fulfill their lives in the easiest way and without needing to sweat (begging). In fact, there are those who describe that they are individuals who have surrendered to fate. Most have a minimal education background and have absolutely no ambition and determination to plan for the future. Not strange indeed, poverty and violence are part of their daily lives (Nadalsyah, 2001: 1).

Nugroho (2003: 96-97) states that the phenomenon of street children including Gepeng is not only the monopoly of developing countries but also in developed countries. In terms of sociology, this phenomenon is often named deviant behavior or behavior that deviates from the order of society. On the other hand, Gepeng is not a mere deviant behavior, but people who are hegemony, exploited, at the same time are marginalized because of their cultural structure and physical environment. Gepeng is a product of poverty and poverty is a product of the workings of the unfair economic-political system of society (Budiasa, 2011).

The paradigm change in handling Gepeng problems needs special attention. Gepeng fostering models that continue to respect human dignity in the process of transforming their lives become interesting and important to study. This research traces the Gepeng empowerment model using spiritual education, better known as the Educare program. In this program, there are no sweeps or Gepeng arrests. Empowerment begins with approaching service as a form of pure love.

\section{Discussion}

\subsection{Practical Formation Process of Gepeng}

Gepeng which has been interpreted as pathological behavior or deviant behavior is a victim of a particular cultural history journey. The most dominant Gepeng that appears in the city of Denpasar is Gepeng originating from Karangasem Regency, precisely in Dusun Muntigunung and Dusun Pedahan. The question that arises is why from the long history this area is actually the dominant area of Gepeng.

Budiasa's research (2011) revealed that the Gepeng habit was inseparable from the environment and culture (objective and subjectivity structure) that developed it historically from its original place of residence, from Dusun Muntigunung to the place where they operated, practicing fattening in Denpasar City. The practice of Gepeng life has historically originated from barter behavior. The process of getting what was not produced in gardening or farming due to limited natural resources and human resources made them go outside the village to barter. Outside the village, they had to adapt because many people were invited to barter, instead of exchanging crops for their gardens or fields with money. Even people outside the village eventually gave more money than exchanging the crop with rice. The rationale of the community at that time was, with money they would be able to obtain principal food namely rice.

In this phase, the practice of Gepeng began. The gloomy tradition has turned into a flat practice, which raises empty hands without bringing the results of the field anymore. The practice of Gepeng in local terms is often mentioned by the term gendendong or baby-snatching. Until now this local term is still used mainly in villages. The internal structure of culture refers to the three internal dimensions of the actors put forward by Anthony Giddens (in Priyono, 2002: 24) in Structural theory. This humiliation in more internal dimensions is motivated by unconscious motives and practical consciousness, but it does not 
require to accentuate discursive consciousness in the practice of Gepeng.

Unconscious motives of Gepeng concerning desires or needs that have the potential to direct the action of fattening, in this case, is the desire and need for money to live. The mechanism of Gepeng life practice is formed through the performance of practical awareness groups. This practical awareness is the key to understanding the process by which social actions and practices gradually become structures, and how structures curb and enable social actions/practices. Discoursive consciousness refers to the capacity to reflect and provide detailed and explicit explanations for the actions taken. This discursive awareness is difficult to describe honestly. Repeatedly doing Gepeng practices have formed a habitus with self-identity as flat. This makes them even more courageous in farther places. The more distant they operate, the more they can hide the identity of the person they know in the area of origin and also have implications for increasing income. The most effective adaptive strategy is to go to areas that have high economies and crowded centers such as tourism and urban areas. Another adaptive strategy that arises later, as a feature of Gepeng practice is to bring a child or baby. This aims to add to the appearance of concern. They will go around holding a baby and holding a child, this is ideal for them to feel worthy of being Gepeng (magegendong).

\subsection{Spiritual Education Mindset (Educare) as an Empowerment Effort}

Gepeng prevention in the Province of Bali is different from the prevention of Gepeng in Java Province or other areas. This is due to different socio-cultural, economic, and geographical backgrounds, resulting in different Gepeng life practices and at the same time different types of coaching efforts. According to Robert Chamber (in Kartasasmita, 1999: 195) expressing community empowerment is an economic development concept that summarizes social values, namely those that are peoplecentered, participatory, empowering, and sustainable.

In the concept used in the Educare program for Gepeng, this often separates the meaning of worldly education and spiritual education (Educare). Spiritual education can easily be contrasted with worldly education. Education (worldly education) is an educational process that tends to use one's ability to look outside (towards the outside world), while Educare (spiritual education) is more oriented to the use of the ability to look inward, develop intuition (inner voice/conscience) for self-realization. The differences can be seen in the table below.

THE DIFFERENCES BETWEEN EDUCATION AND EDUCARE

\begin{tabular}{|l||l||l|}
\hline & EDUCATION & EDUCARE \\
\hline \hline SOURCE & World & Heart \\
\hline \hline PHILOSOPHY & Survival \& upmanship & Harmony with Creation \\
\hline \hline ATTITUDE & Greed \& aggression & Love \& compassion \\
\hline \hline APPROACH & Competition & Co-operation \\
\hline \hline MANIFESTATION & Selfish grabbing & Selfless service \\
\hline
\end{tabular}

(Sumber: http://www.saibaba.ws/articles2/educare_and_education.htm)

Looking at the boundaries of the education and Educare concept, coaching carried out on Gepeng by the community adoption program looks more oriented to the Educare, without putting aside worldly education. With the spread of Gepeng cases in Denpasar city, then in addition to coaching efforts that have been carried out by government agencies, Gepeng has also become the center of attention of several 
concerned groups of non-governmental or non-political organizations.

Sai Youth Denpasar is a youth organization under the Sai Study Group Indonesia (SSGI) Foundation. The Sai Study Group Indonesia is an organization that operates in three wings, namely spiritual wings, services (seva) wings, and education wings. Sai Youth believes that the most basic capital to be able to interact, be accepted, and transform values, especially to Gepeng, is the existence of purity, sincerity, and how to be a good example. The facilitation and teaching model activities, including each lesson plan given in the Community Adoption, are adapted to the Gepeng character by emphasizing human values.

Community Adoption develops more essential patterns to provide new glow in the Gepeng coaching program that is inspiring and functions multi-effect. This program represents an effort to emancipate social Gepeng carried out by conducting Community Adoption.

\subsection{Spiritual Education Empowerment Mechanism (Educare)}

The Educare program in the process of fostering Gepeng is divided into several phases, namely the approach, guidance, and evaluation phases. The first phase is the approach phase. Approach efforts in the context of this development initially experienced several difficulties. Gepeng is difficult to approach because they have been traumatized by raids and police officers or Tramtib and Satpol PP officers. In this approach phase, the Community Adoption Team concentrates on getting closer to increasing the frequency of interactions. The interaction between the Community Adoption and Gepeng Team took place in the operating area and also in the origin of Gepeng. Then interactions were carried out with children and their families in the area of origin, namely in Dusun Muntigunung, West Tianyar Village. The purpose of this interaction is for children to feel comfortable and safe in the middle of the Team. On the other hand, the Gepeng parents believe that the existence of the Community Adoption Team is purely for the sake of the emancipation of their children.

After doing the approach phase, the next stage is the second phase, namely coaching.

Gepeng formation begins with making an Educare lesson plan design by holding a meeting held every Saturday afternoon. The coaching design is directed in such a way that it can foster confidence, independence, and trust in God's power. In this formation phase, they are trained to sit quietly (meditation), sing songs, share stories, pray according to their religion, share togetherness, and play in group activities.

The PNK methods used include praying and sitting quietly, teaching, storytelling, singing songs, playing (games), and practicing about self-disclosure in various 'groups of activities'. Krishna (2006: 21) revealed in 'sitting quietly', trained in self-respect, calmed, and freed himself from all anxiety. Through the 'group activities', participants are nurtured to maintain the mind by carrying out services with all their heart, inviting them to only think and act well. This will function to resist the influence of useless thoughts and erratic thoughts, reduce desires, increase selfdiscipline until the state of mind and action leads us towards a healthier and more peaceful life. Every step in this coaching activity such as praying, sitting quietly, singing, playing, and telling stories are always themed humanitarian values education, which is expected to inspire Gepeng to transform the flattened character of lazy people or the habit of begging to be independent characters and believe in themselves. In this case, there is a process of formation towards emancipatory behavior.

Program evaluation is always carried out in the process of fostering efforts, also conducted research on their expectations. Begging is not their real hope. The practice of Gepeng is a cultural construct that they must face and strive to be able to change. A Gepeng practice represents the game of life as well as the champ that they have to run. 
Bourdieu (1980 in Haryatmoko, 2003: 1415) reveals like a magnetic field, the field of struggle is understood as a field of strength. He became a place of struggle between individuals, between groups.

The intention of high learning of Gepeng represents them to have Unconscious motives to emancipate themselves or develop behavior that is considered social pathology. Coaching is done more with understanding and being aware of the mental state of children. The team has the ideology that continuous awareness of both children and their parents will be able to change the minds of "begging" into more independent characters, so that on the way children are not directly prohibited from begging, but awareness is slowly growing and its character building that is not at all commendable, that the practice of Gepeng will destroy their future.

Efforts to foster Gepeng in the Community Adoption program, also use the mentoring process until the interaction process into the building environment of the building agent. This learning process functions to change the internal structures (unconscious motives, practical consciousness, and discursive consciousness) of Gepeng faster. The main content of the pattern of formation of Community Adoption, in terms of spiritual education towards Gepeng, is to implement Human Value Education, which functions as character building. It develops five human values found in all people. These five spiritual values are the basis of all religions. The five values are (1) truth, (2) good or virtuous behavior, (3) peace, (4) love, and (5) without violence. The five values are called core values. Each of these core values is further divided into children of values, for example, the core values of 'truth' include values of honesty, self-inquiry, respect for all religions, intuition, perfection, and others. Then some values of 'love' are tolerance, sympathy, friendship, devotion, sincerity, humanity, and others. Likewise, the translation of the other values is adjusted to the needs of the coaching participants.
Material development is based on situations and conditions but still based on Human Value Education with emphasis on 'love' values. Discourses developed for example .."love.in .the.mind,.that.is.the.truth", "love in action, that is good behavior, that is a virtue", "love in that feeling is peace", and "love plus understanding is without violence".

The learning process carried out in the framework of planting EHV is done by the method of prayer, sitting quietly/meditation, stories, singing, playing, discussions, and dialogue. The prayers used in EHV are simple and universal prayers for all religions. The purpose of this prayer is to foster faith and trust in God in accordance with the religion adopted. Gepeng from Muntigunung is entirely Hindu, seeing homogeneity in the belief system, so the prayer that is often used in addition to universal prayer is Vedic mantras like Omkaram, Ganesha Puja from Reg. Vedas, Gayatri Mantram, Mantra for the gods like Lord Shiva, Devi, Guru, Sarwa names and others. Silent sitting is a method of meditation. There are various types of meditation, but there are at least five simple meditation methods commonly used in this Educare, namely (1) sitting silence, (2) light meditation or Jyotir meditation (light meditation) or often also called love meditation, (3) Japa or Namasmarana namely repeating the name of God (repeat the name of Lord/God), (4) contemplating/imagining

God (contemplation/imagine of God), and (5) So Ham (Upanishadic mantra for repetition and focus). Of the five types of meditation, sit quiet and light meditation are the most often used in this Gepeng spiritual education program.

Stories containing human values are effective tools in the EHV system. In addition to stories, singing methods are also used in establishing human values. Gepeng invited to sing happily. The type of song is songs that are able to build good character. This song is in the form of songs that adore the greatness of God, songs of spiritual 
awakening to build good self-character, songs that evoke happiness and spirituality such as smiling songs or songs that are created based on the creativity of a fostering agent whose theme is to build good character. Given that all Gepeng are Hindu, then the songs that are often taught are also songs of gods such as Om Namah Shiva Ya, Krishna, Rama, and others.

Of all the EHV teaching methods, game (group activity) is what makes the participants laugh the most. Each game has meaning that participants must explore themselves or discuss something at the end of the game. The game components have been prepared by EHV building agents. For example, group games compile randomized words. Participants must arrange these words so that they become actual sentences that can build their character. Other games, for example, games to make rope formation in accordance with the direction of the building agent, and others. All games, in the end, will invite the participants to reflect on the meaning of the game. Every time they are invited to build character (character building). EHV ends by praying again. All of the above methods are applications of the learning process as planting and strengthening ethical values from the conscious mind to the subconscious mind.

The evaluation phase is always done in stages. Based on observations and evaluations of the Community Adoption Team carried out on Gepeng who had participated in the coaching program in Denpasar City, it was seen that there had been a change. From now on, it has never been sprung up again where they normally operate. Some have switched professions to become fruit sellers in Kumbasari Market. There are also those who live in their home areas, namely Dusun Muntigunung. The process of social emancipation which is the main goal of the development program seems to be successful in this regard with various potentials and constraints that exist.

\subsection{The Application of Spiritual Cultural Values Strategy in the Field of Empowerment}

When compared to the coaching program carried out by the government and the Community Adoption Team from the guidance system carried out, it appears that the Community Adoption program with the application of spiritual education (Educare) is deeper in applying spiritual cultural values. The application of the EHV (Education Human Value) method, Medicare (spiritual service in terms of health), Sociocare (social service) in the empowerment process strengthens the nuances of the application of spiritual values.

In Hinduism, it is revealed that spiritual is not merely a ritual practice but also teaches about service practices (seva/service). This is widely stated in the Vedas and its sacred literature such as revealed in the Bhagavata Purana which reads "Na thwaham Kamaye Rajyam, Na Swargam napnu arbhawam kamaye Dukha thapthamam, Praninam aarrthi naasanam" (Oh God I pray not to ask for position in the kingdom, nor to beg for Heaven or manifest as a great human being. I just begged You to give me strength and opportunity to serve those who suffer). Then in Rg. Veda 1.15.8 states that "May we be able to devote ourselves to being instruments of God Almighty and can share our fortune with the poor and those in need". So is the concept in the Vedas about Vasudhaivakutumbakam which means that all beings are family and Tat Twam Asi who mandates "I am You".

In the EHV or PNK method used in coaching practices, there are main values which are often referred to as the five pillars, which consist of sathya (truth), dharma (virtue), prema (love), shanti (peace) and ahimsa (without violence). All these human values are taught in Hinduism. Basically, PNK instills and strengthens these spiritual values to become guidelines and characters in coaching participants. This development aims to change Gepeng habitus to become habitus which is full of 
ethical values so that the practice of Gepeng can be eliminated. The development of Gepeng with the Educare program is to instill ethical values through the sprained conscious mind towards the subconscious mind so that there is a transformation in their character. The end result of education is a good character.

The practice of the Community Adoption agent represents the application of the Sai Organization's significant structure based on the Sad Guru discourse (often called mahawakya). An example of one of the speakers about EHV can be seen from the passage below.

"Humans must develop humanity by pursuing both education (worldly education) and Educare (spiritual education). Education means that knowledge is gained through learning from books written by other people. But Educare isn't like that. It comes from the heart. It is a hidden power possessed by humans that must be made a reality through sadhana (spiritual practice). The human values of Sathya, Dharma, Shanti, Prema, and Ahimsa must always be applied in real life.

Mahawakya above shows the significant structure in the education and Educare domain. This is an attempt to build emancipatory behavior. Mahawakya is also a structure of dominance and legitimacy in driving the Educare program, especially in handling Gepeng problems and society in general.

\section{Conclusion}

The existence of Gepeng practices is due to negative dogmatism that has emerged in the historical journey which is quite difficult to emancipate. The Educare program is a spiritual education program that seeks to build awareness or arouse knowledge in humans to practice human values so that the process of selfemancipation or character building takes place. The impact of empowerment with the Educare program on Gepeng includes (1) the emergence of social emancipation in Gepeng, namely the process of enlightenment of ignorance due to dogmatism of knowledge through a process of self-reflection; (2) empowerment, namely there is continuous excavation and strengthening (empowerment) of selfpotential; (3) positive restructuring, namely the existence of internal efforts to restructure the original cultural order flattened strong towards the direction expected by the general public; and (4) access to productive modalities, that is after they have been trained they have more modalities to be able to live more productively.

\section{References}

Anonim. 2008. Sri Sathya Sai Baba Organization. Diakses 18 Pebruari 2008.

URL:http://www.sathyasai.org/organiz e/content.htm Sai

Organisations.htm\#act.

Anonim, 2011. Kekerasan terhadap Gepeng Dikecam. Radar Bali 4 April. Hal 25 kol 3.

Bourdieu, Pierre. 1977. Outline of a Theory of Practice. England: Cambridge University Press.

Budiasa, I Md. 2011. Potensi Aplikasi Nilai Budaya Spiritual Hindu dalam Ranah Pembinaan Gepeng (Sebuah Studi Penerapan Pendidikan Spiritual [Educare] dalam Praktik Kehidupan Gepeng Muntigunung di Kota Denpasar) Denpasar:IHDN Denpasar

Buntoro, T. R. 2006. Arti Seorang Ibu Bagi Bangsa. Murali Sai. Vol. 02: 13-18.

Giddens, Anthony. 2004. The Constitution of Society, Teori Strukturasi untuk Analisis Sosial. Malang: Pedati.

Hardiman, F. Budi. 1993. Мепијu Masyarakat Komunikatif. Ilmu, Masyarakat, Politik \& Posmodern Menurut Jurgen Habermas. Yogyakarta: Kanisius. 
Haryatmoko. 2003. Landasan Teoritis Gerakan Sosial menurut Pierre Bourdieu, Menyingkap Kepalsuan Budaya Penguasa. Basis No. 11-12, Tahun ke 52: 4 - 23.

Kalangie, Nico S. 1994. Kebudayaan dan Kesehatan. Pengembangan Pelayanan Kesehatan Primer melalui Pendekatan Sosio-Budaya. Jakarta: Penerbit Erlangga.

Kartasasmita, Ginandjar. 1999. Power dan Empowerment. Sebuah Telaah mengenai Konsep Pemberdayaan Masyarakat dalam Pembebasan Budaya-budaya Kita. Editor Agus R. Sarjono. Jakarta : PT Gramedia dengan Pusat Kesenian Jakarta Taman Ismail Marsuki.

Khrisna. 2006. Pendidikan Nilai-nilai Kemanusiaan. Murali Sai. Volume 02: 13-18.
Nadalsyah, R.E. 2001. Gepeng Siapa Peduli. Kompas, 15 April. diakses 30 Oktober 2006;

URL: http://www.kompas.com/index.htm .

Nugroho, Heru. 2003. Menumbuhkan Ideide Kritis. Edisi Revisi. Yogyakarta: Pustaka Pelajar.

Pemerintah Provinsi Bali. 2005. Dokumen Strategi Penanggulangan Kemiskinan Daerah Provinsi Bali Tahun 2005$2009 . \quad$ Denpasar: Komite Penanggulangan Kemiskinan Daerah (KPKD).

Priyatna, Elan. 2003. Emansipasi Intelektual Menurut Jurgen Habermas. Bandung: Katarsis. 